\title{
Improvements to the operation of wind power generators in Vietnam
}

\author{
Nâng cao hiệu quả hoạt động của nguồn điện gió trong hệ thống điện Việt Nam \\ Research article
}

Do, Nhu Y*; Le, Xuan Thanh

Hanoi University of Mining and Geology, Vietnam

\begin{abstract}
In Vietnam, the number of wind power generators has been increased yearly. Because of geophysical characters, the generation of these generators has different properties. It depends much on wind's characteristics as well as the generation technology. Based on simulation implemented on Matlab, the paper analyzes the stability of national networks at PCC nods containing the connection of wind power station when there is a change of wind's velocity or when there is an earth fault in grid. The analyzing results are used to suggest solutions to improve the stability and effectiveness of the whole system.
\end{abstract}

Các nhà máy điện gió đang ngày càng gia tăng ở Việt Nam, do cấu tạo địa lý nên đặc điểm của nguồn điện này khá khác biệt so với các nguồn điện truyền thống khác. Nguồn điện gió phu thuộc nhiều vào đặc điểm của gió và công nghệ sử dung để phát điện gió. Nội dung chinh của bài báo là khảo sát mức độ ổn định của luơoi điện kết nối các nguồn điện gió tại nút kết nối chung khi có sư thay đổi về tốc độ gió hoặc khi trong mạng xảy ra sụ cố chạm đất thoáng qua, tù đó đề xuất giải pháp nâng cao ổn định, tin cậy và nâng cao hiệu quả làm việc của hệ thống.

Keywords: wind power, stability, STATCOM, Malab Simulation

\section{Introduction}

Renewable energy and wind energy have rich future not only in Vietnam but also in develop countries. Based on the research of World Bank, the capacity of wind power in Vietnam is about 513.360MW. The areas containing rich wind energy resources are Cuu Long Delta and island ones [1]. The detail geological distribution of wind energy resources are shown in figure 1.

In Vietnam wind's characters and wind's modes depend much on areas and seasonal properties. Wind is rich on high land areas; its velocity is also big. These characteristics affect strongly on operation modes of wind power stations. Some characters of wind in Vietnam are shown in figure 2 [2].
In wind power station, the generators are usually double feed induction ones. They are mainly consumed a huge amount of power system's reactive power to maintain rotating field in themselves stator and rotor. Therefore, in some special cases called disturbances such as: wind changing, earth fault, short circuit, the applied voltage of generator is reduced dramatically. If the time of disturbances is over long, the generation system will be unstable, the generator's speed can not come up to the previous one [6]. Consequently, the generators are disconnected from national system; the reliability of electric supply will be reduced. Therefore, this phenomenon must be limited to improve the effectiveness of wind power station's operation. 

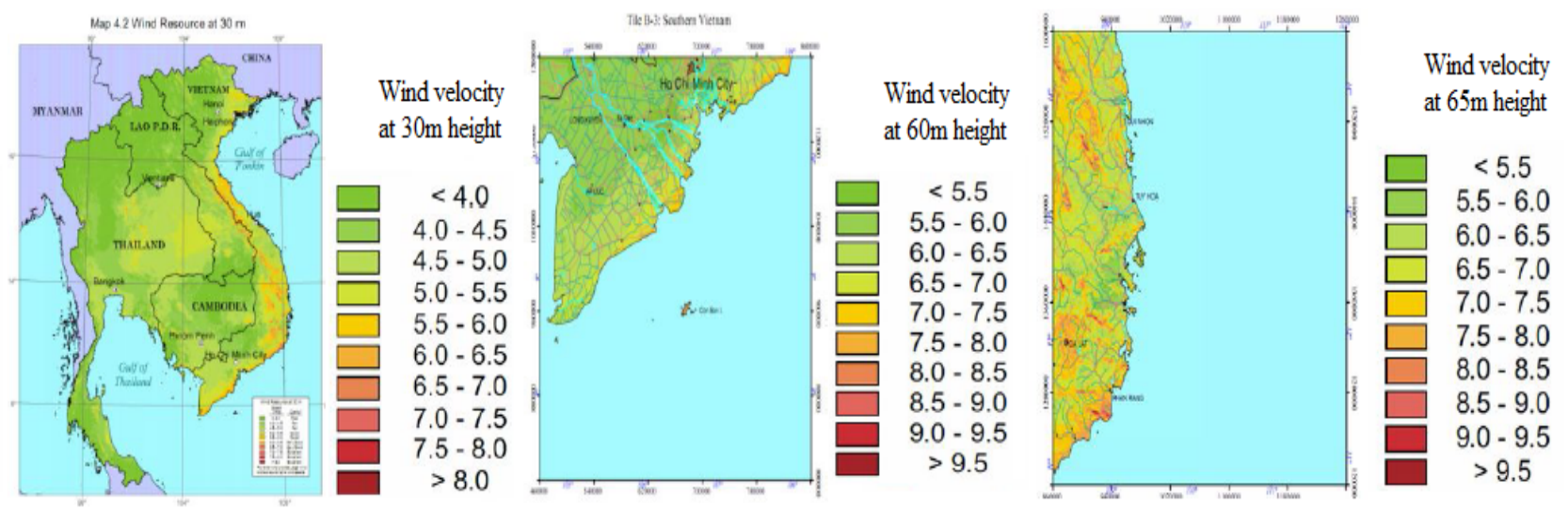

Figure 1. Wind energy resources of Vietnam (source World Bank)
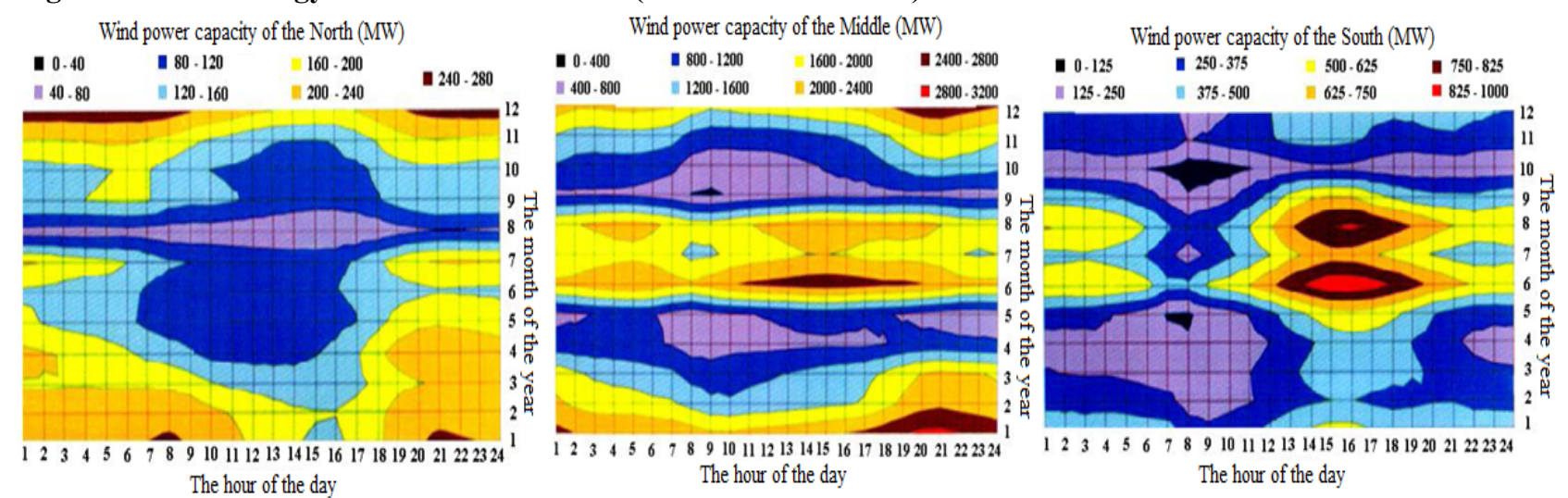

Figure 2. Characteristics of wind in Vietnam areas

\section{Research models}

The connection of wind power stations and grid could be implemented at different voltage level. It depends on either power supplying by stations or the distance from the station to the connection points. The general connection diagram of a typical wind power station and a grid is shown in figure 3 [2], [3], [6].

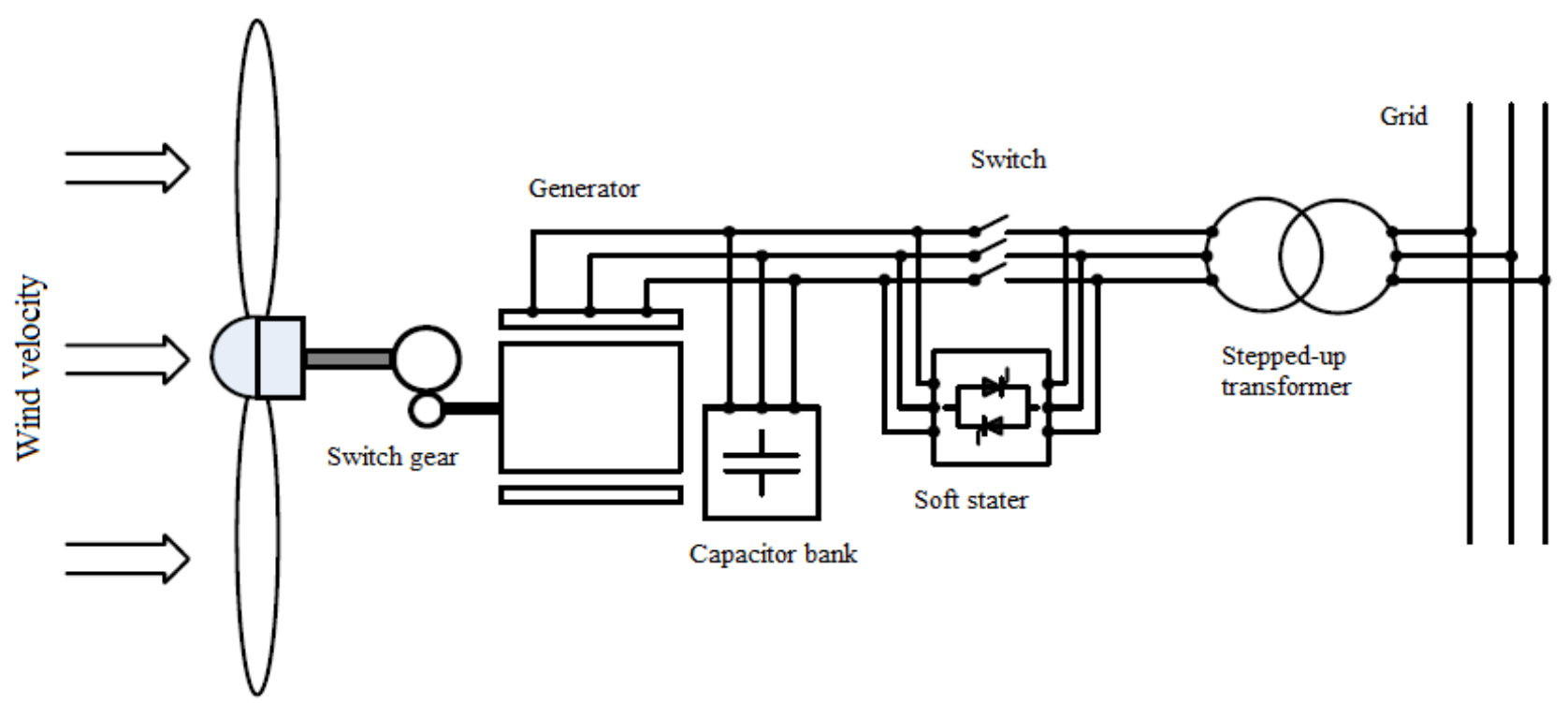

Figure 3. The connection diagram of wind power station and national grid

Figure 4 presents the model of 9MW wind power station containing 3 turbines (each of $3 \mathrm{MW}$ ). The station is connected to the $22 \mathrm{kV}$ distribution grid at PCC, named B22. The power generated by station is transmitted to $110 \mathrm{kV}$ grid by $20 \mathrm{~km}$ lines of $22 \mathrm{kV}$. Generators in station are squirrel-cage induction type; the wind's velocity is $9 \mathrm{~m} / \mathrm{s}$. Each generator has its own protection system to ensure their voltage, current and speed. A compensated capacitor having the value of $400 \mathrm{kVAr}$ is connected at the coming end of generator, the entire power needing to maintain voltage at B22 equal by $1 \mathrm{pu}(22 \mathrm{kV})$ is supplied by STATCOM 3MVAr. 


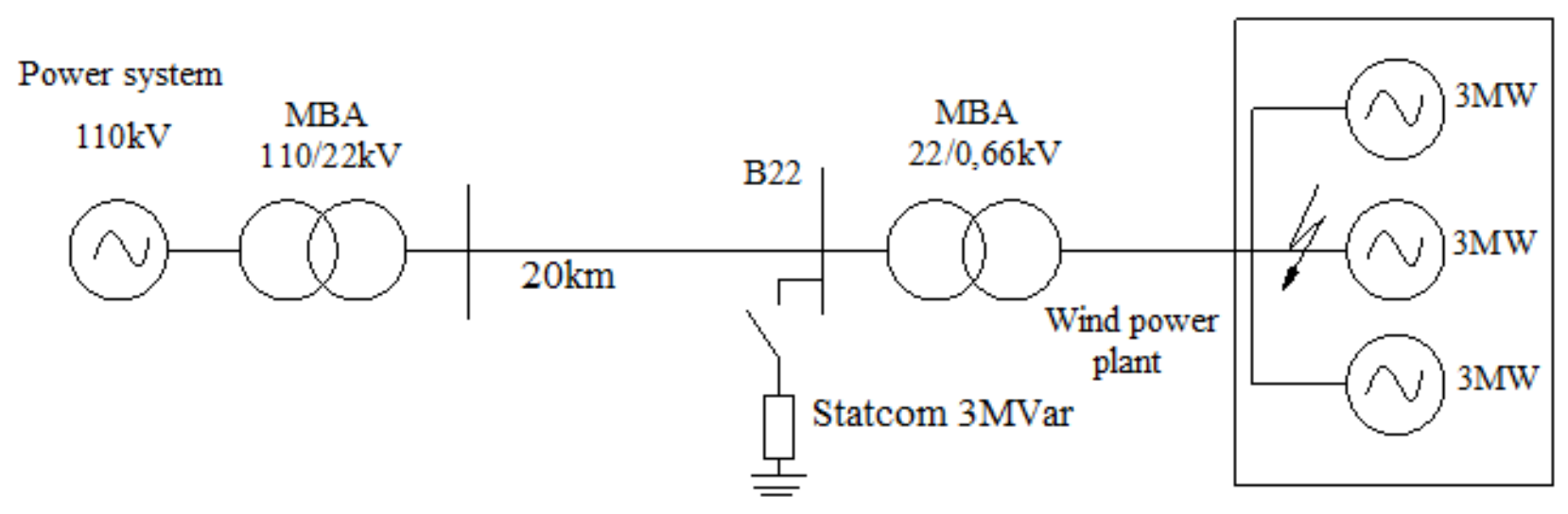

Figure 4. Model of wind power station connected with national grid

Statcom in above mentioned diagram is a FACTS device; it can convert DC voltage into AC to compensate reactive power for power system. The basic components of a Statcom is shown in figure 5 [5], [7].

Matlab structures of a STATCOM is presented in figure 6, whereas:

VSC-Voltage Source converter;

$\mathrm{V}_{\mathrm{dc}}-\mathrm{DC}$ voltage.

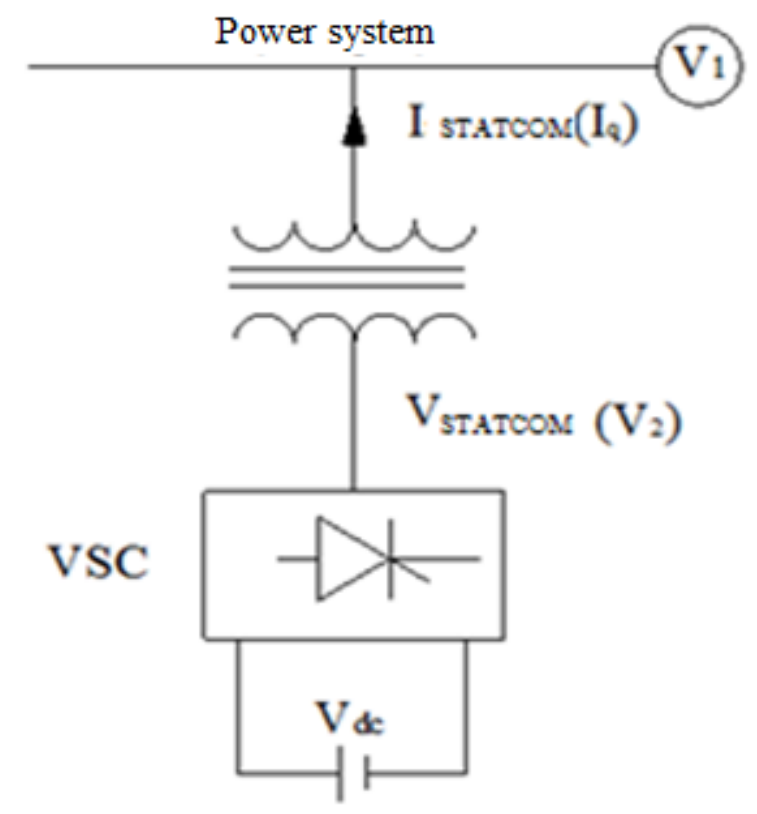

Figure 5. Basic components of a STATCOM

A Statcom operates on the principle that: VSC changes the power (both active and reactive ones) on the primary side of transformer to make the corresponding changing of system voltages $V_{1}$ and $V_{2}$. Typical blocks of a STATCOM are presented in figure 6 [4].

Utilizing a STATCOM in figure 6, a simulation model is formed in figure 7 that is used to analyze the effectiveness of STATCOM in improving the operation of wind power station.

The simulation is implemented with the following data: The velocity of wind is $8 \mathrm{~m} / \mathrm{s}$, at the time of $2 \mathrm{~s}$, it is increased to $11 \mathrm{~m} / \mathrm{s}$. The wind's velocity flowing into $2^{\text {nd }}$ and $3^{\text {rd }}$ turbines is also increased correspondingly at $4 \mathrm{~s}$ and $6 \mathrm{~s}$. At $t=15 \mathrm{~s}$, and earth fault is occurred on the output pole of generator 2. The results showing the responses of system
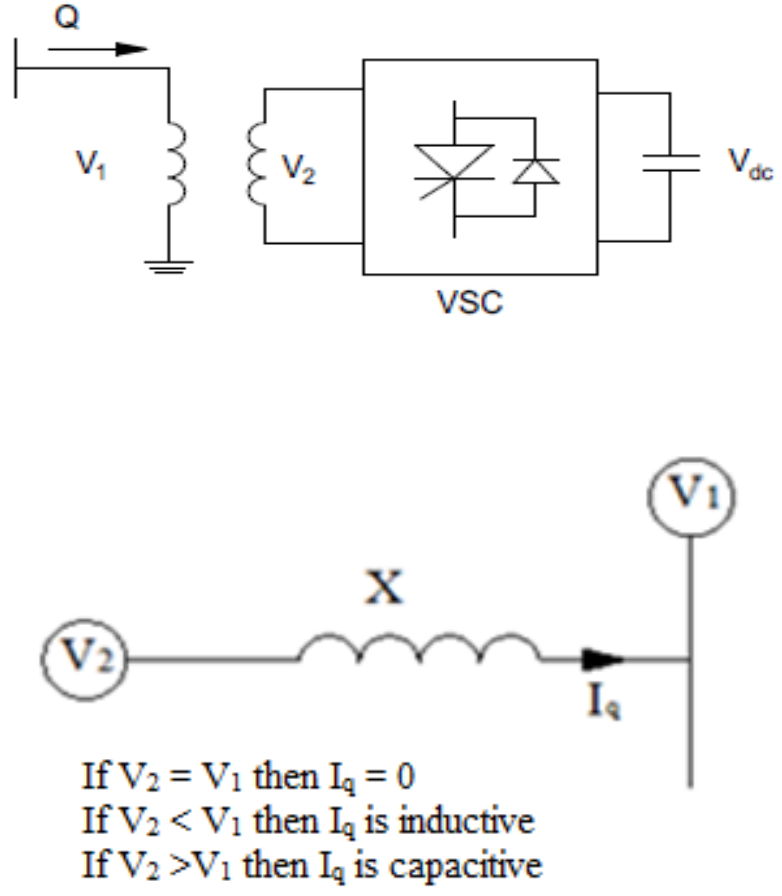

corresponding to 2 cases: using STATCOM and do not using STATCOM are presented in figure 8.

The simulation proved that, when the wind's velocity is over rated one $(9 \mathrm{~m} / \mathrm{s})$, active power generated by generator is increased, but its consuming reactive power is also increased.

When the STATCOM is not utilized at B22, because of lacking reactive power, the bus's voltage is only $0,92 \mathrm{pu}$ (at $\mathrm{t}=8 \mathrm{~s}$ ), consequently the generator is overload. The generator stops its operation at $t=13,2 \mathrm{~s}$. Latter on, because of generator 2 and 3 still operate well, the emitted power is $3 \mathrm{MW}$, and voltage is recovered around $0,98 \mathrm{pu}$.

When the STATCOM is utilized, because the reactive power is compensated by STATCOM at B22, voltage is 
not sag. The voltage remains at $0,98 \mathrm{pu}$ (figure $8 \mathrm{~b}$ ) there is no disconnected of the system.

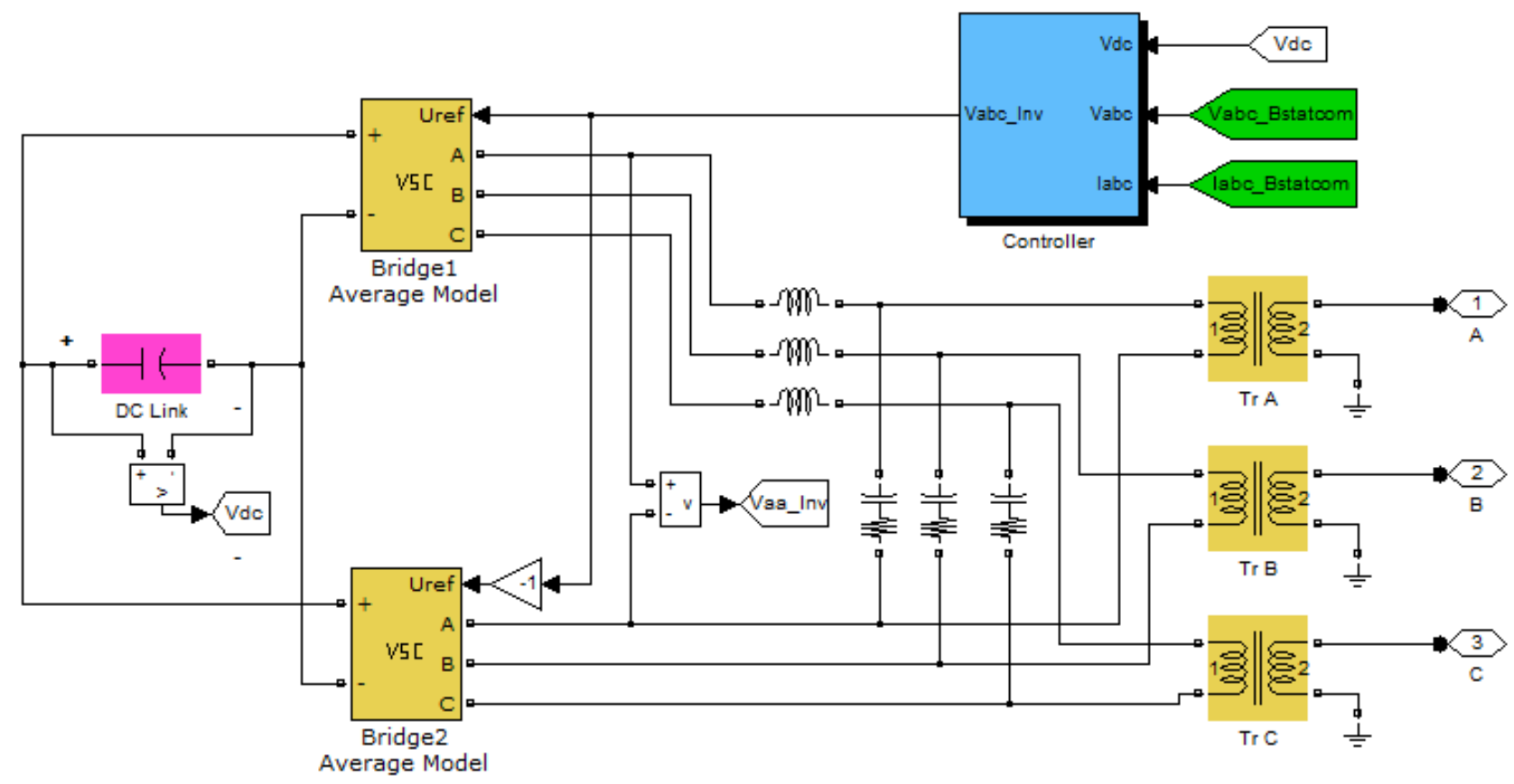

Figure 6. Typical block diagram of a STATCOM

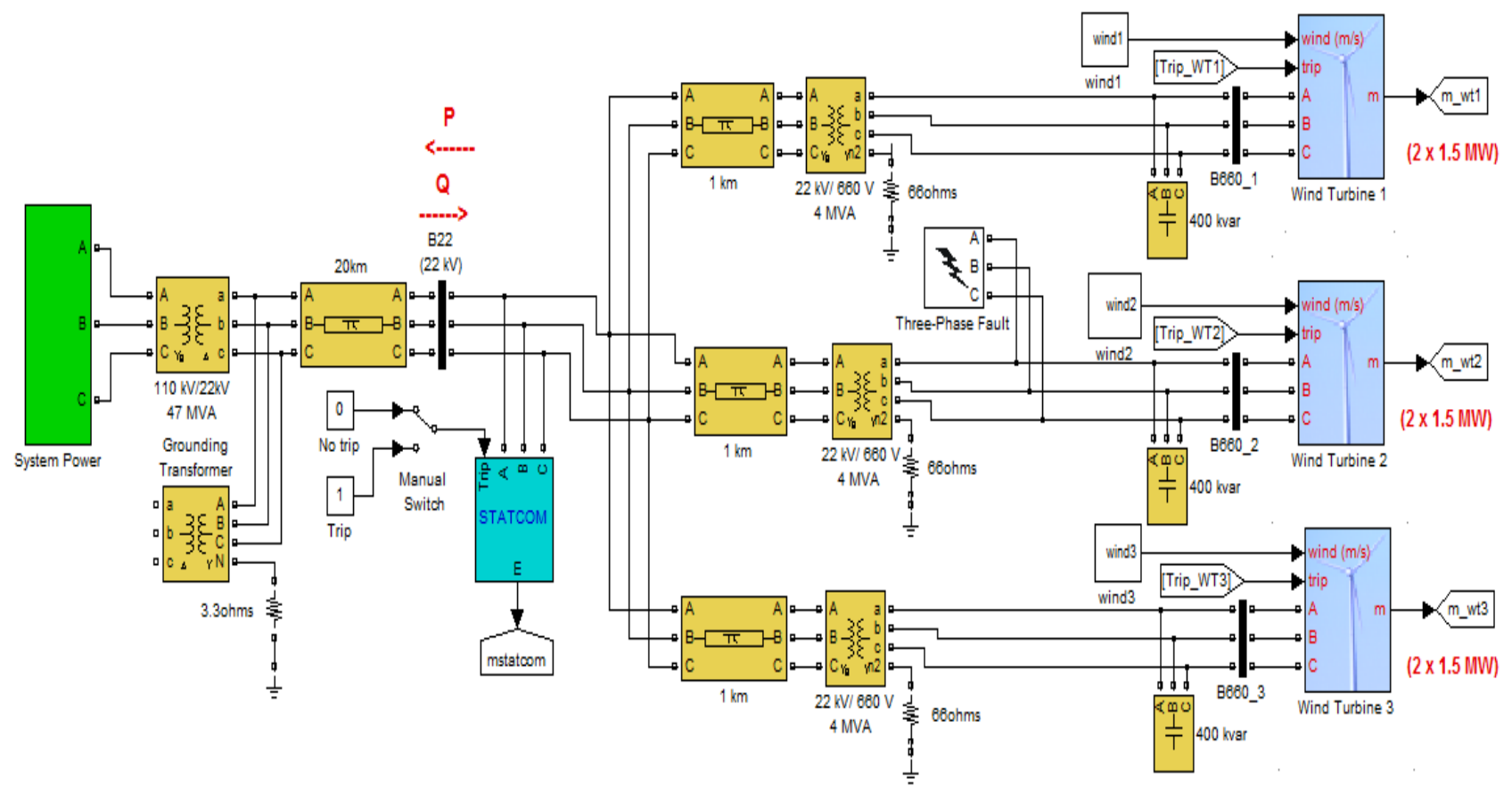

Figure 7. Matlab-Simulink simulation of a wind power station connected to the grid 

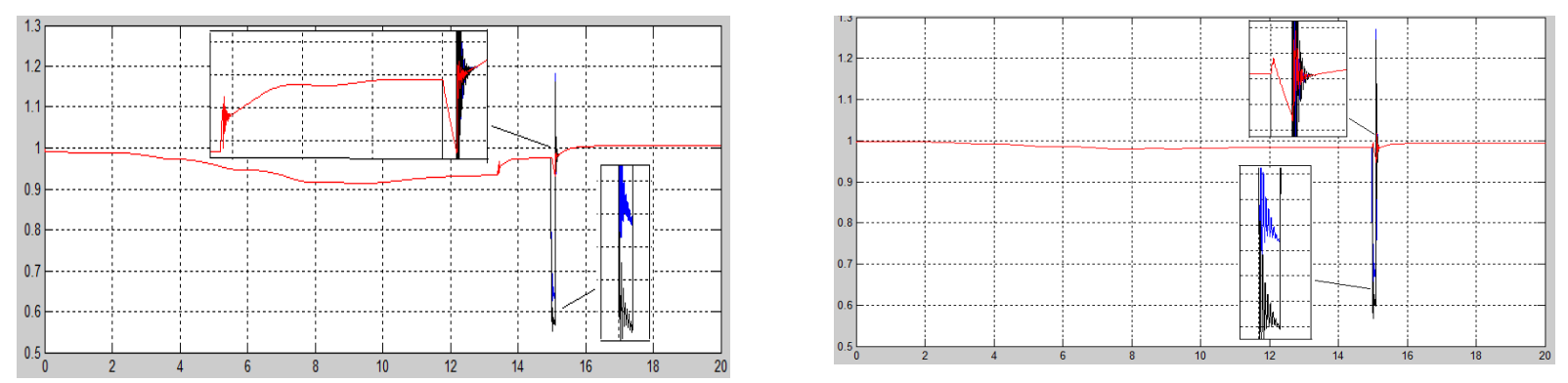

Figure 8. Voltage wave form at the bus B22

a - use Statcom; b - do not use Statcom

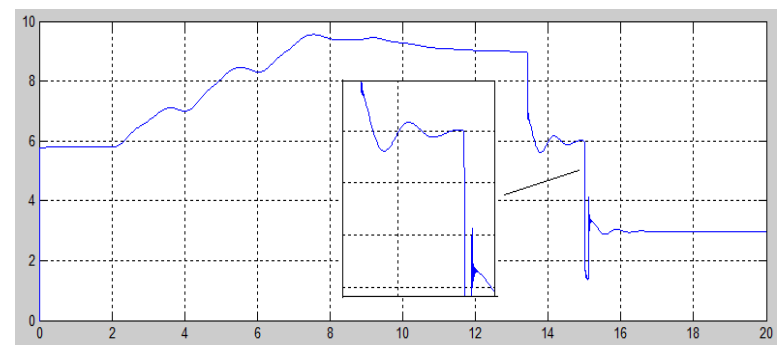

a)

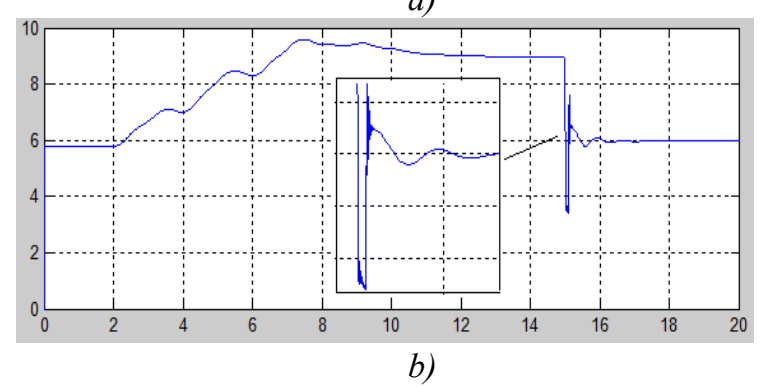

Figure 9. Active power $P$ at bus $B 22$

$a$ - use Statcom; $b$-do not use Statcom

The similar simulation is implemented with earth fault on generator 2 . At $t=15 \mathrm{~s}$ the disturbance is occurred with generator 2 , voltage is down to $0,52 \mathrm{pu}$, the protection system isolated the generator 2 from the system.

Without using STATCOM, the system is only stable after $2 \mathrm{~s}$.

The active and reactive power of 2 cases mentioned above are shown in figure 10.
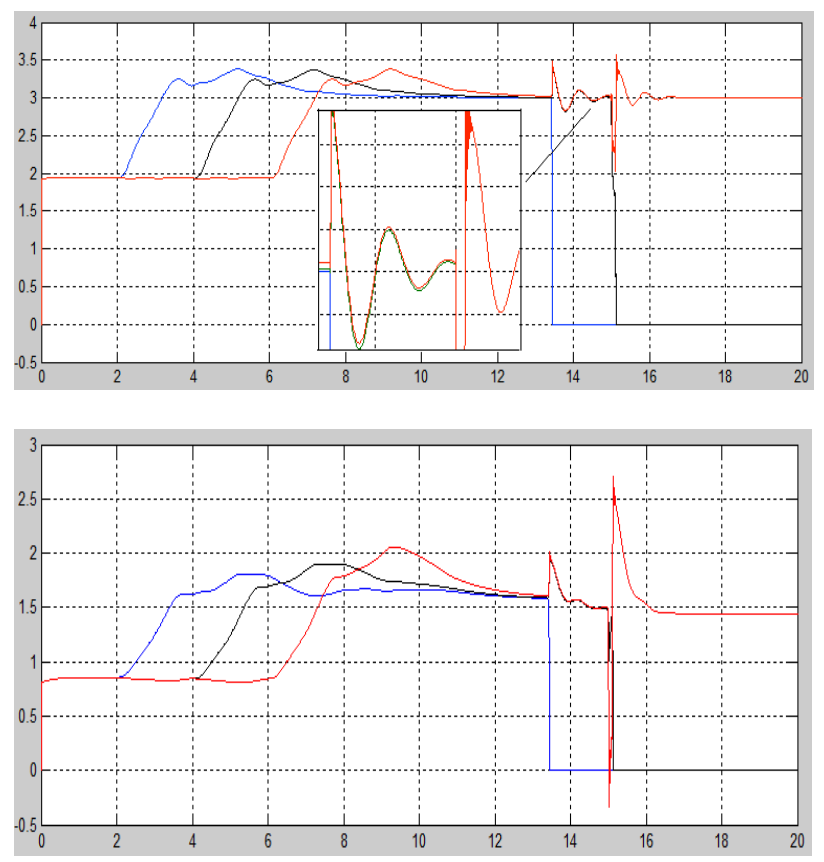

a)
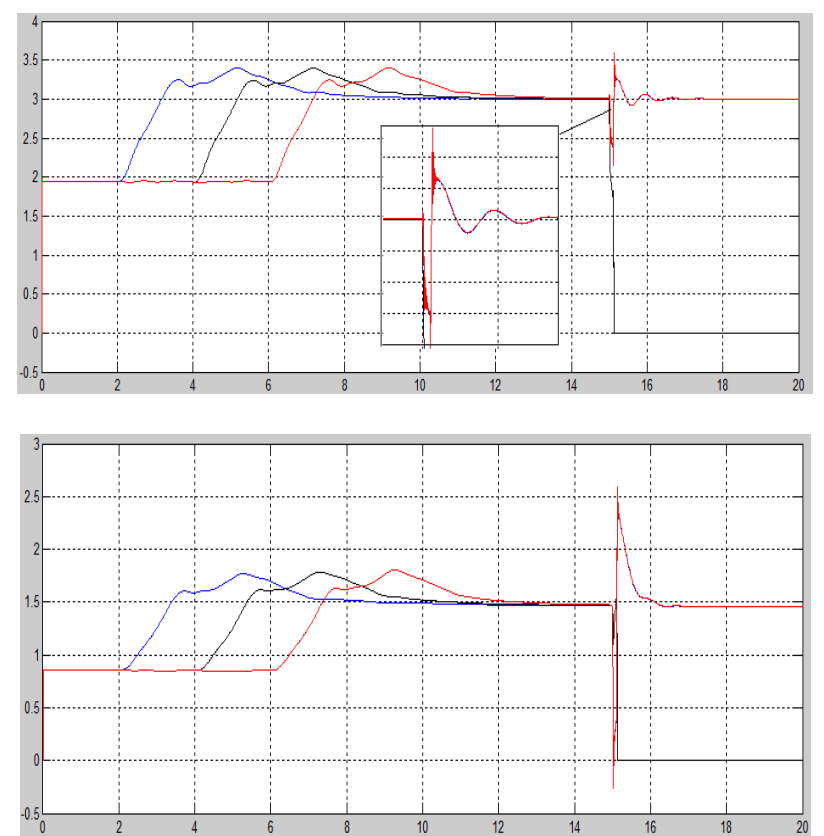

b)

Figure 10. Active power $P$ generated by turbines and reactive power $\mathbf{Q}$ consuming by turbines

$a$ - use Statcom; $b$-do not use Statcom 


\section{Conclusion}

The results which are shown in above simulation proved that with STATCOM the interval of system's disturbance is lower significantly. The system is operated more stable even when there is the change of wind's velocity or abnormal operation such as earth faults.

Another advantage of using STATCOM is the out put voltage of generators is in better performance; this will help to protect generators from unwanted mechanical shocks and to lengthen the age of wind turbine.

\section{References}

[1] World Bank, "Wind energy resource atlas of southeast east Asia", True Wind Solutions, LLC, 2001.

[2] Department of Dispatch centre in VietNam, Forum
"Building up the regulations of wind power connection and research for renewable energy in Vietnam", Hanoi, 2014.

[3] Ho Van Hien, The transmission and distribution power system, Science and Technology Publishing House, 2005

[4] Do Nhu Y, Research for using STATCOM to improve the power quality of mining electric system, Mining Scientific Journal No 6-2015.

[5] Применение гибких (управляемых) систем электропередачи переменного тока в энергосистемах, В. И. Кочкин, Ю. Г. Шакарян, $311 \mathrm{c}-2011$

[6] J.G. Slootweg; Wind Power: Modelling and Impact on Power System Dynamics; PhD thesis ; Technische Universiteit Delft; (2003).

[7] Flexible AC Transmission Systems (FACTS), Yong Hua Song ; Allan T. Johns, 610tr-1999. 